\title{
Predictors of Sexual Debut Among Young Adolescents In Nairobi's Informal Settlements
}

By Milly Marston, Donatien Beguy, Caroline Kabiru and John Cleland

Milly Marston is lecturer, and John G. Cleland is emeritus professor-both at the London School of Hygiene and Tropical

Medicine, London.

Donatien Beguy is research scientist and head of the Statistics and Surveys Unit, and Caroline Kabiru

is research scientist and head of the

Urbanization and

Wellbeing Research Program-both at the African Population and Health Research Center, Nairobi, Kenya. CONTEXT: There is a need to better understand the various social, psychosocial and behavioral factors associated
with sexual activity among young adolescents in various settings in Sub-Saharan Africa.

METHODS: Data were drawn from Wave 1 (2007-2008) and Wave 2 (2009) of the Transition to Adulthood study, which collected information about key markers of the transition to adulthood and social, demographic and psychosocial characteristics of male and female youth living in two informal settlements in Nairobi, Kenya. Logistic regression analyses were used to examine variables associated with experience of sexual debut by Wave 2 among youth who were aged 12-16 and sexually inexperienced at Wave 1.

RESULTS: Of the 1,754 youth in the sample, 92 experienced sexual debut between survey waves. For both males and females, sexual debut was positively associated with having permanently dropped out of school (odds ratios, 6.9 and 21.8, respectively), having never attended school (8.6 and 39.4) and having experienced severe family dysfunction (2.8 and 5.7). Lack of parental supervision was a predictor of sexual debut among males only (10.1), whereas low aspiration was a predictor among females only (10.4). Surprisingly, young women, as well as men, who did not have high self-esteem were less likely than those who did to initiate first sex between waves (0.4 and 0.3 ).

CONCLUSIONS: Study findings underscore the importance of school attendance, family dysfunction, parental supervision and self-esteem in driving sexual behavior in this age-group. Further studies are warranted to elucidate how these factors can be addressed in prevention programs for young adolescents.

International Perspectives on Sexual and Reproductive Health, 2013,39(1):22-31, doi: 10.1363/3902213
Since the 1994 International Conference on Population and Development, the protection of adolescents' sexual and reproductive health has been a social and policy priority for many governments and nongovernmental organizations in Sub-Saharan Africa. Addressing the sexual and reproductive health challenges faced by adolescents in the region is critical, given the high number of new HIV infections among young people and the large contribution adolescent childbearing makes to the high levels of fertility observed in many Sub-Saharan African countries. ${ }^{1}$ In fact, improved sexual and reproductive health among adolescents is likely to raise women's status and reduce poverty among families. ${ }^{2}$

In Sub-Saharan Africa, the onset of sexual activity typically occurs by age 20 and often earlier. ${ }^{3}$ Sexual debut exposes young adolescents to myriad negative sexual and reproductive health outcomes. Adolescents who initiate sex at young ages are more likely than those who do not to have multiple and concurrent partners, engage in unprotected sexual intercourse and acquire STIs, including HIV. ${ }^{4,5}$ Early sexual intercourse also increases the risk of unwanted pregnancies, which are associated with poor health outcomes for both mother and child., ${ }^{6,7}$ Young people often terminate unwanted pregnancies through clandestine induced abortions, which can lead to maternal complications, including death. ${ }^{8}$ Also, children born to ad- olescent mothers are more likely than those born to older women to be underweight and premature, and to die during their first month. ${ }^{9,10}$ Further evidence associates early unintended pregnancy with poor educational and employment opportunities. ${ }^{5,9}$ Therefore, there is a need to better improve the understanding of the various social, psychosocial and behavioral factors associated with sexual activity among young adolescents in various settings in SubSaharan Africa, to inform the design of appropriate sexual and reproductive health programs and interventions.

Although there is abundant data on the sexual and reproductive behaviors of older adolescents and young adults (aged 15-24) in Sub-Saharan Africa, little is known about younger adolescents (12-16 years). Yet, it is now widely recognized that it is necessary to target adolescents before they engage in sexual activity, to understand and address their sexual and reproductive health needs. ${ }^{11}$ Recent evidence from four countries in Sub-Saharan Africa suggests that a significant minority of young people aged 12-14 are already sexually active. ${ }^{12,13}$ In addition, a sizeable proportion of young people become sexually mature between the ages of 12 and 16, when females typically have their first menstruation, and males experience pubertal physical changes. ${ }^{14-17}$ As many young adolescents are still in school, they should be able to be targeted through school-based sexual and reproductive health programs and interventions. 
This article, therefore, seeks to contribute to the scant literature on young adolescents in Sub-Saharan Africa by examining the transition to first sex among males and females aged 12-16 living in two informal settlements, or slums, in Kenya's capital city of Nairobi. Living in a slum is a threat to young people's development, as it increases their risk of HIV infection, risky sexual behaviors, early childbearing, and other adverse sexual and reproductive health outcomes. ${ }^{12,18,19}$

It is important to have a better understanding of young adolescents' sexual behavior to inform policies and programs designed to improve sexual and reproductive health outcomes. Using a modified version of the protection-risk conceptual framework developed by Jessor et al., ${ }^{20-24}$ we examine factors associated with sexual debut among young adolescents living in such deprived environments. Unlike previous research, this study uses longitudinal data, which allows us to control for temporal ordering. Data collected at baseline are used to explain events that occurred by the subsequent wave. Much of the existing literature on factors that influence sexual behaviors among youth in Sub-Saharan Africa is based on a demographic or health point of view. In addition, we use a psychological and developmental perspective that accounts for a wide range of individual, family and behavioral variables.

\section{THEORETICAL FRAMEWORK}

Our conceptual framework stems from the paradigm that, during adolescent development, events that mark the transition to adulthood-including initiating sexual intercourse, getting a job and having children-are tolerated at older ages, but socially proscribed at earlier ages. The experience of these events at early ages is, therefore, seen as a departure from social norms, and could be considered problem behavior. Jessor et al. ${ }^{20-24}$ developed the Problem Behavior Theory, which provides a comprehensive framework to explain behaviors such as drug use, alcohol abuse, delinquency and early sexual debut in the United States. ${ }^{23}$ The theory posits that two groups of common psychosocial root causes drive engagement in problem behaviors. Protective factors are negatively associated with problem behaviors, because they provide models or a supportive environment for conventional behavior and controls against problem behavior. Risk factors, on the other hand, increase the chances of engaging in problem behaviors, and include models for unconventional behavior, ${ }^{22,23,25-27}$ opportunities for deviant behavior, and greater personal vulnerability to engaging in unconventional behavior.

So far, the framework has been successfully applied and adapted to explain a wide range of deviant behaviors among adolescents in various contexts and subgroups beyond the United States, where it was developed. ${ }^{28-30}$ The Problem Behavior Theory has been shown to account for significant portions of variance in problem behavior among adolescents in the United States and elsewhere. ${ }^{22,23,25,27,31}$ Given the adverse health, social and economic consequences ascribed to sexual debut as a young adolescent, we posit that it can be qualified as problem behavior. Therefore, the framework is relevant to the study of sexual debut among adolescents aged 12-16 living in Nairobi's informal settlements.

We hypothesize sexual debut to be associated with family composition and characteristics, personal characteristics, school attendance and participation in social groups among both young men and young women. In terms of family characteristics, we expect absence of parental figures, low family supervision, marital breakdown and violence, and sibling risk behavior to be risk factors for early sexual debut. Among personal traits, non-Muslim religion, low religiosity, low personal aspirations for schooling and employment, and self-reported delinquent behavior (e.g., fighting and stealing) will likely be positively associated with sexual debut as well. We hypothesize that nonattendance at school and low social participation will be risk factors for males and females, and that high self-esteem will be a risk factor for males, but not females, because of enhanced confidence in seeking sexual partners. ${ }^{32}$

\section{METHODS \\ Setting}

This study was conducted in two informal settlements, or slums, in Nairobi: Korogocho and Viwandani. Overall, an estimated $60-70 \%$ of the population in Nairobi live in slums or slumlike conditions, ${ }^{33}$ and in 2009, more than one-third of residents in Korogocho and Viwandani were living below the poverty line. ${ }^{34}$ These settlements are characterized by limited access to health, education and other social services and amenities; poor housing, sanitation and infrastructure; high rates of unemployment, HIV and substance use; and pervasive violence, including sexual and gender-based violence. ${ }^{19,35-37}$ In addition, slum residents tend to have inadequate knowledge of contraception, as well as limited access to family planning services. ${ }^{38}$

Although the settlements are characterized by the extreme deprivation and challenges described above, many people are drawn to them from elsewhere in Kenya, because of their proximity to the capital's center and availability of low-cost housing, which has led to their rapid growth. The two study sites have many commonalities, although there are marked differences between them. Korogocho-one of the city's most congested slums-is home to residents who have lived there for years. On the other hand, Viwandani, which is located in the city's industrial area, attracts a youthful, highly mobile migrant population seeking employment in local industry.

\section{Data and Sample}

We used data from the Transition to Adulthood study, which investigated protective and risk factors of youth aged 12-24 in Korogocho and Viwandani, and how such factors influence young people's transition to adulthood. The study design has been described elsewhere. ${ }^{39,40}$ Briefly, the study was nested in the Nairobi Urban Health and Demographic Surveillance System (NUHDSS), a longitu- 
dinal platform set up in 2002 by the African Population and Health Research Center to collect and monitor health and demographic data from residents living in the two settlements. A sample of youth aged 12-22 were randomly selected for interview from NUHDSS household records. All respondents gave signed or verbal consent before being interviewed; consent was required from a parent or guardian for youth aged 12-17. Ethical clearance for the study was obtained from the Kenya Medical Research Institute's ethical review board.

Overall, 4,058 young people were interviewed during the survey's first wave, conducted between October 2007 and June 2008, and 2,674 adolescents were interviewed during the second wave, conducted between March and August, 2009. Time between interviews ranged from 0.8 to 1.8 years. In both waves, participants were surveyed in their homes by trained interviewers using a fully structured instrument; interviews were conducted in Swahili, the common language in the settlements. Questions were social, demographic and psychosocial in nature, and related to key markers of transition to adulthood, such as schooling, employment, sexual intercourse, marriage and parenthood.

\section{Measures}

Our outcome-early sexual debut-measured respondents' reporting at Wave 1 that they had never had sex and then their reporting at Wave 2 that they had had sex. We defined early sex as intercourse before age 18-the age of legal adulthood in Kenya. This cutoff also takes into account the median age at first sex, which on the basis of data from the 2008-2009 Kenyan Demographic and Health Survey ${ }^{41}$ and preliminary analyses of the timing of first sex in the Transition to Adulthood study is approximately 18 years. Consequently, by restricting our sample to the group of sexually inexperienced youth aged 12-16 at Wave 1, we were able to capture those who first had sex between waves, when they were aged 13-17.

We included several social and demographic variables, all captured at Wave 1. Age was measured as a continuous variable; sex, settlement of residence and Muslim religion were dichotomous variables. School attendance was a categorical variable with response options "always in school," "dropped out," "restarted" and "never in school." Also included were questions on whether the respondent had a mother or father figure in his or her life.

In addition, nine psychosocial measures were constructed on the basis of Jessor's theoretical framework ${ }^{42}$ and adapted to reduce the number of parameters. Those that were binary were made into categorical variables, and those that were scaled were combined into composite measures, using a unidimensional factor analytic model;

*The self-esteem scale includes variables with general self-perceptions, as well as perceptions that are more domain-specific. We carefully examined these sets of variables separately in the models, as well as together as a scale. Each individual variable works in the same direction with varying levels of significance, but with no changes to the results of other variables in the model. Therefore, for brevity of style, we include them in a single self-esteem scale. internal consistency was assessed using alpha reliability (Kuder-Richardson Formula 20 for dichotomous variables and Cronbach's alpha reliability coefficients for others). ${ }^{43}$ As most of the scaled variables did not follow a normal distribution and were in some cases highly skewed, they were grouped using appropriate cut points. Categorization also allowed a dummy category to be created when measures were not applicable for some respondents, for example "no guardian" for the family supervision measure.

The first psychosocial measure-delinquent behaviorwas created from questions asking how many times in the four months prior to the survey respondents had engaged in certain activities (e.g., started a fight with a peer, took or tried to take something that belongs to someone else, delivered or sold drugs or alcohol). Response options were "never," "once" or "more than once"; Cronbach's alphas were 0.67 for males and 0.59 for females. A measure of family supervision was based on respondents' perception of how often their parents or guardians know about such things as where and with whom they spend time, and how they spend their money (1="never know" to 3="always know"); Cronbach's alphas for males and females were 0.87 and 0.84 , respectively. Religiosity was based on four questions about the importance of God, prayer, and religious teachings and beliefs (1="not important" to 4="very important"); Cronbach's alphas were 0.77 for males and 0.74 for females. A personal aspirations measure was created from questions asking how important respondents believed it is to finish secondary school, go to university and have a good job (1="not important" to 4="very important"); Cronbach's alphas were 0.71 for males and 0.74 for females. Parental support was based on six questions, such as "How often does your father/father figure teach you things you didn't know?" and "How often does your mother/mother figure try to help you when you need something?" (1="never" to 5="all the time"); Cronbach's alphas for males and females were 0.63 and 0.58 , respectively. A categorical measure of sibling risk behavior was created from dichotomous questions of whether respondents' siblings had ever had premarital sex, smoked cigarettes, or used alcohol or drugs. Family dysfunction was measured by six dichotomous questions, such as "In the past three months has your family/household suffered because your parent(s)/guardian(s) were out of a job?" and "Has a parent or other adult living in your home ever hit you hard enough to cause injury?" (Kuder-Richardson Formula 20 coefficients, 0.63 for males and females). A self-esteem measure was based on five questions asking respondents their perceptions about how well they get along with peers and live up to others' expectations of them, how able they are to do well in school, how attractive they are and how satisfied they are with themselves overall.* Response options were on a four-point scale that ranged from "very" to "not at all"; Cronbach's alphas were 0.62 for males and 0.61 for females. Finally, social participation was measured by whether respondents belonged to such groups as a religious club, sports team or choir. 
Several measures of peer influence were included: whether respondents knew if any close friends had been kissed, had been fondled or had had sex, and whether friends approved of drugs or alcohol. In an exploratory analysis, however, these measures were not found to be associated with early first sex and were excluded from the main analysis.

\section{Analysis}

For our analyses, we restricted the sample to sexually inexperienced youth aged 12-16 at Wave 1 who also completed an interview at Wave 2. Of the 1,894 adolescents aged 12-16 interviewed at Wave 1, 1,754 reported never having had sexual intercourse. Seventy percent (638 males and 591 females) were reinterviewed at Wave 2; non-Muslims, youth not in school and females who had experienced family dysfunction were less likely to be reinterviewed, but in other regards, loss to follow-up did not significantly affect sample composition.

All analyses were stratified by sex and conducted using Stata 11.1. We used multivariable logistic regression analyses to investigate associations between early sexual debut and social, demographic and psychosocial variables. Crude odd ratios were calculated for individual variables separately and assessed. One variable-parental support-was not associated with sexual debut, and was not included in the adjusted models because of problems of collinearity. Models were run with social and demographic variables and all other psychosocial variables separately before a final adjusted model with all variables was run.

Forced or coercive sex may play a role in early sexual debut among females. Thus, we repeated our analyses among only the young women in our sample who had been willing at first sex. In addition, in the absence of accurate information on the dates of school discontinuation and sexual debut, an association between school attendance and sexual debut would be causally ambiguous, insofar as sexual experience may result in pregnancy and forced school dropout. To examine this more closely, we conducted analyses among all females, excluding those who reported becoming pregnant between waves.

\section{RESULTS}

Among the overall sample of young adolescents, more than half of males and females were from the Viwandani slum (56\% and 53\%, respectively; Table 1). The vast majority were not Muslim (84\% and 87\%) and had always attended school (83\% and 84\%). Virtually all youth (98\%)

\begin{tabular}{|c|c|c|c|c|c|}
\hline Characteristic & $\begin{array}{l}\text { Males } \\
(\mathrm{N}=638)\end{array}$ & $\begin{array}{l}\text { Females } \\
(\mathrm{N}=591)\end{array}$ & Characteristic & $\begin{array}{l}\text { Males } \\
(\mathrm{N}=638)\end{array}$ & $\begin{array}{l}\text { Females } \\
(\mathrm{N}=591)\end{array}$ \\
\hline \multicolumn{3}{|l|}{ Residence } & \multicolumn{3}{|l|}{ Religiosity } \\
\hline Korogocho (ref) & 44.5 & 47.6 & Important/very important (ref) & 78.2 & 85.2 \\
\hline \multirow[t]{2}{*}{ Viwandani } & 55.5 & 52.5 & Somewhat/not important & 13.9 & 11.9 \\
\hline & & & No religion & 7.9 & 2.9 \\
\hline \multicolumn{6}{|l|}{ Muslim } \\
\hline No (ref) & 83.5 & 86.8 & Personal aspirations & & \\
\hline \multirow[t]{2}{*}{ Yes } & 16.5 & 13.2 & Very important (ref) & 94.0 & 94.9 \\
\hline & & & Quite/not important & 6.0 & 5.1 \\
\hline \multicolumn{6}{|l|}{ School attendance } \\
\hline Always in school (ref) & 82.9 & 83.9 & Parental support & & \\
\hline Dropped out & 8.6 & 7.8 & $>$ half the time & 79.8 & 88.7 \\
\hline Restarted & 4.2 & 4.1 & $<$ half the time & 19.3 & 10.5 \\
\hline Never in school & 4.2 & 4.2 & No parent & 0.9 & 0.9 \\
\hline \multicolumn{3}{|c|}{ Is there anyone like a father in your life? } & \multicolumn{3}{|l|}{ Sibling risk behavior } \\
\hline Yes (ref) & 77.9 & 79.7 & No smoking or sex (ref) & 65.8 & 68.0 \\
\hline \multirow[t]{2}{*}{ No } & 22.1 & 20.3 & Smoking/sex & 10.8 & 8.5 \\
\hline & & & Don't know & 19.8 & 21.7 \\
\hline \multicolumn{3}{|c|}{ Is there anyone like a mother in your life? } & No sibling & 3.6 & 1.9 \\
\hline Yes (ref) & 97.5 & 98.3 & & & \\
\hline \multirow[t]{2}{*}{ No } & 2.5 & 1.7 & Family dysfunction & & \\
\hline & & & Low (ref) & 59.1 & 60.5 \\
\hline \multicolumn{3}{|l|}{ Delinquent behavior } & Middle & 30.7 & 29.7 \\
\hline None (ref) & 49.2 & 64.1 & High & 10.2 & 9.7 \\
\hline \multirow[t]{2}{*}{$\geq$ once } & 50.8 & 35.9 & & & \\
\hline & & & Self-esteem & & \\
\hline \multicolumn{3}{|l|}{ Family supervision } & High (ref) & 51.4 & 53.3 \\
\hline Always (ref) & 27.5 & 38.8 & Medium/low & 48.6 & 46.7 \\
\hline Sometimes & 57.6 & 56.0 & & & \\
\hline Never & 13.5 & 4.9 & Social participation & & \\
\hline \multirow[t]{2}{*}{ No guardian } & 1.4 & 0.3 & No groups (ref) & 17.2 & 20.8 \\
\hline & & & $\geq 1$ groups & 82.8 & 79.2 \\
\hline Total & 100.0 & 100.0 & Total & 100.0 & 100.0 \\
\hline
\end{tabular}

Notes: ref=reference group. na=not applicable. Percentages may not add to 100.0 because of rounding. Religiosity measures respondents' perception of the importance of God, prayer, and religious teachings and beliefs. Personal aspirations measures respondents' perception of the importance of their finishing secondary school, going to university and having a good job. Self-esteem measures respondents' feelings of how well they get along with peers and live up to others' expectations of them, how able they are to do well in school, how attractive they are and how satisfied they are with themselves overall. 
TABLE 2. Percentage distribution of youth who experienced early sexual debut, by selected characteristics, according to gender

\begin{tabular}{|c|c|c|}
\hline Characteristic & $\begin{array}{l}\text { Male } \\
(\mathrm{N}=53)\end{array}$ & $\begin{array}{l}\text { Female } \\
(\mathrm{N}=39)\end{array}$ \\
\hline \multicolumn{3}{|l|}{ Relationship to first partner } \\
\hline Husband/wife & 0.0 & 7.7 \\
\hline Live-in partner & 1.9 & 0.0 \\
\hline Noncohabiting boy/girlfriend & 86.8 & 87.2 \\
\hline Casual acquaintance & 9.4 & 0.0 \\
\hline Other & 1.9 & 5.1 \\
\hline \multicolumn{3}{|l|}{ Relative age of partner } \\
\hline Younger & 34.0 & 0.0 \\
\hline Same age & 45.3 & 10.3 \\
\hline 1-9 years older & 15.1 & 64.1 \\
\hline$\geq 10$ years older & 0.0 & 10.3 \\
\hline Older, but don't know difference & 1.9 & 10.3 \\
\hline Don't know & 3.8 & 5.1 \\
\hline \multicolumn{3}{|l|}{ Reason for first sex } \\
\hline Married & 1.9 & 7.7 \\
\hline Natural feeling & 77.4 & 71.8 \\
\hline Partner insisted & 5.7 & 5.1 \\
\hline Influence of friends & 13.2 & 0.0 \\
\hline Forced & 0.0 & 15.4 \\
\hline Don't know & 1.9 & 0.0 \\
\hline \multicolumn{3}{|l|}{ Willingness at first sex } \\
\hline Very & 77.4 & 51.3 \\
\hline Somewhat & 20.8 & 30.8 \\
\hline Not at all & 1.9 & 18.0 \\
\hline \multicolumn{3}{|l|}{ Contraceptive use at first sex } \\
\hline None/traditional method & 61.5 & 63.2 \\
\hline Condom & 38.5 & 34.2 \\
\hline Other modern method & 0.0 & 2.6 \\
\hline Total & 100.0 & 100.0 \\
\hline
\end{tabular}

had someone like a mother in their life, whereas fewer $(78-80 \%)$ had someone like a father. Half of males and $64 \%$ of females had not engaged in delinquent behaviors in the previous four months. When asked how often their parents or guardians know how they spend their time and money, $28 \%$ of males said always, $58 \%$ sometimes and $14 \%$ never; for females, the proportions were 39\%,56\% and $5 \%$. Religiosity was high, as were personal aspirations, with $78-95 \%$ of youth reporting religion and aspirations as being important or very important. Two-thirds of youth (66\% of males and $68 \%$ of females) did not have a sibling who engaged in risk behaviors; $59-61 \%$ reported low family dysfunction. Just over half of males and females reported having high self-esteem (51\% and 53\%). Social participation was common: Eighty-three percent of males and $79 \%$ of females reported belonging to at least one social group, and $45 \%$ reported belonging to two or more (not shown).

Between Waves 1 and 2, 53 males and 39 females initiated sexual intercourse. Among the young women, 10 had gotten married or begun cohabiting, and 18 had become pregnant. Eighty-seven percent each of males and females reported that their first sexual partner was a noncohabiting boyfriend or girlfriend (Table 2). The vast majority $(85 \%)$ of females had partners who were older, whereas the majority $(79 \%)$ of males had younger or same-aged partners. The most commonly reported reason for first sex among males and females was "natural feeling" ( $77 \%$ and $72 \%$, respectively); the next most common reason among young men was peer pressure (13\%) and among young women was having been forced (15\%). Eighteen percent of females were not at all willing at first sex; the proportion among males was $2 \%$. Three in five young people reported using no method of protection at first sex.

In the unadjusted logistic regression models for males, most variables were found to be associated with early sexual debut at at least the $90 \%$ confidence level (Table 3): age, Muslim religion, school attendance, presence of a father figure, family supervision, religiosity, personal aspirations, sibling risk behavior, family dysfunction and social participation. In the final adjusted model, several factors other than age were positively associated with early sexual debut. Young men who had permanently dropped out of school and those who had never attended were more likely than those who had always attended school to have initiated first sex between waves (odds ratios, 6.9 and 8.6, respectively). In addition, males who reported not having a guardian had greater odds of sexual debut than those who reported that their parents or guardians always knew about their activities (10.1). Young men from families with severe dysfunction had greater odds of sexual debut than did those from families with low dysfunction (2.8). However, having medium or low self-esteem and belonging to at least one social group were each negatively associated with initiating sex (0.4 each).

For females, age, Muslim religion, school attendance, presence of a mother figure, delinquent behavior, family supervision, personal aspirations, sibling risk behavior and family dysfunction were associated with early sexual debut at the $90 \%$ confidence level (Table 3). In the final adjusted model, having permanently dropped out of school and not having ever attended school were strongly and positively associated with initiating sex among young women (odds ratios, 21.8 and 39.4, respectively). In addition, females who reported that their personal aspirations were not very important or that their family had high dysfunction also had elevated odds of sexual debut (10.4 and 5.7, respectively). Surprisingly, women who did not have high self-esteem were less likely than those who did to experience early sexual debut (0.3). Associations between early sexual debut and Muslim religion, family supervision and religiosity were only marginally significant.

In our additional analyses among young women who reported being willing at first sex, the results were similar to the overall model, with two exceptions (not shown). Young women with siblings who smoked or had had sex were more likely than those with siblings who had not engaged in such behaviors to have initiated sex (odds ratio, 4.3; 95\% confidence interval, 1.1-16.7). In addition, age was not significant. In our analyses excluding women who had become pregnant between waves, the results were also similar to the overall model, except that the odds of sexual 


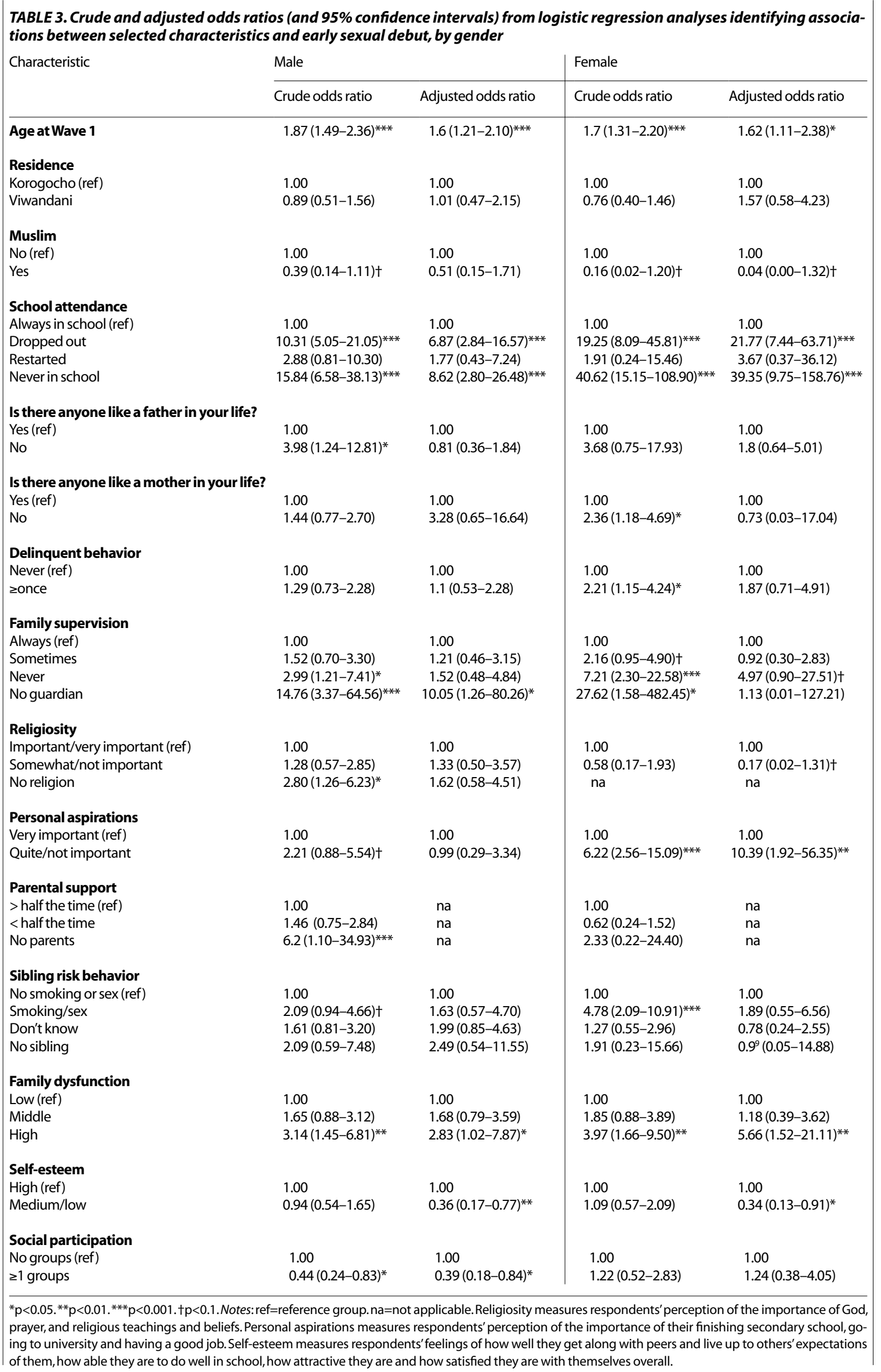


debut among those who had permanently dropped out of school were lower (8.7); the odds of sexual debut among those who had never attended school were the same.

\section{DISCUSSION}

Early sexual debut exposes adolescents to numerous negative sexual and reproductive health outcomes that can impair positive development. ${ }^{4,5}$ Although the drivers of sexual behavior among older adolescents and young adults have been widely studied in Sub-Saharan Africa, there is a dearth of information on sexual behavior among very young adolescents. To our knowledge, this study is the first to examine a wide range of social, demographic and psychosocial predictors of sexual debut among 12-16-year-olds using a prospective design and, therefore, it advances the literature on sexual behavior among young adolescents.

Overall, we found that the factors associated with early sexual debut within the high-risk environment of the slums appear to be similar to those in more favorable settings. For example, severe family dysfunction was a predictor of sexual debut for males and females. Previous studies in the United States have shown that women who experience severe family dysfunction or adverse life experiences are more likely than others to initiate sexual intercourse by age $15 .^{44}$ Also, our finding that $15 \%$ of females reported force as the dominant reason for first sex is similar to the finding that $14 \%$ of young women in Uganda had been coerced at their first sexual experience. ${ }^{42}$ Sexual coercion and family dysfunction are likely to be underreported in surveys. ${ }^{45}$

Among males only, lack of parental supervision was a predictor of early sexual debut. Previous studies have shown that parental monitoring is associated with a delay in first sex. ${ }^{4-48}$ It is unclear whether there are programs that work best to increase parental involvement in reducing risk behaviors among adolescents. Religion, religiosity and aspirations were marginal predictors of early sexual debut among females only, which can be explained by genderspecific moral codes and the fact that females have potentially more to lose from engagement in sexual relationships. The influence of religiosity is consistent with findings from the United States. ${ }^{49}$ The impact of young women's aspirations for schooling and employment has potentially important policy implications. Policies and programs that encourage such aspirations and provide better employment opportunities for females are likely to reduce early sexual debut.

Social participation was negatively associated with early sexual debut among males, but was not associated with debut timing among females. In this population, the vast majority of adolescents reported involvement with at least one group, and almost half reported involvement with two or more. Participation in largely secular communal activities has been little studied in developing countries; however, the literature suggests that such activity is protective against behaviors such as substance use, early sexual behavior and delinquency, by providing exposure to positive role models and social networks that encourage conventional or positive social behaviors. ${ }^{9,50}$ The nonsignificant finding among females is puzzling and needs to be further investigated. Even so, efforts to curb early sexual debut among young adolescents living in resource-poor and high-risk settings might have success by increasing participation in such social activities.

Our most surprising result was the association in the adjusted model (but not the unadjusted one) between self-esteem and early sexual debut among females, as well as males. It appears that adolescents who perceived themselves to be attractive and were the most socially confident were more likely than others to become sexually active at an early age. This is surprising, as one would expect young women with high self-esteem to be in control and able to make healthy choices in terms of their sexual behaviorand thus able to resist the pressures to engage in early sex. For males, this situation could be related to the fact that their sexual prowess is often socially endorsed. Therefore, those with high self-esteem might be more likely to "take advantage" of this endorsement and initiate sex as early as they can.

The most important finding, perhaps, is that school appears to protect both males and females against early sexual debut. Previous studies conducted in several SubSaharan African countries have shown that young people enrolled in school are less likely than those not in school to report sexual activity. ${ }^{46,51,52}$ It could be argued that the association of early sexual debut with having never been in school or having dropped out among young women may reflect greater dropout rates due to pregnancy and underrepresentation of sexually experienced females. Yet, even when we excluded young women who became pregnant between waves, these variables were associated. Efforts to increase access to quality schools for all children and to reduce dropouts may, therefore, have direct or indirect effects on improving health outcomes. Indeed, one recent study in rural Zimbabwe provides modest support for the hypothesis that schooling protects against HIV infection. ${ }^{53}$

\section{Limitations}

Findings from this study should be interpreted in light of several limitations. First, we could not control for potential confounding variables that may jointly influence some of the independent variables and early sexual debut, as they were not collected during the survey. Another limitation is the loss to follow-up between waves, which reduced sample size; however, apart from a higher rate of follow-up among Muslims and, for males, a lower rate of follow-up among those not currently in school, those followed up appeared to be similar to those who were not followed up. We would expect this not to have a significant effect on our analysis. In addition, the study relied on self-reported information on sexual debut, which is subject to bias. Also, only a small number of respondents reported first sexual intercourse between waves, which resulted in lower precision and explains the wide confidence intervals observed 
for study estimates. Finally, our dependent variable-early sexual debut-is problematic to objectively define, as one would wonder how young is too early? We define early as younger than 18, which is the median age at first sex in the area. We repeated the analysis restricting our sample to 12-15-year-olds at Wave 1, who would then be younger than 17 at sexual debut, and although our sample size was dramatically reduced, the results were the same as those presented.

These limitations notwithstanding, the study's prospective design increases our confidence in the causal pathways leading to early sexual debut among 12-16-year-olds, who are often "forgotten" in studies on adolescents' sexual and reproductive health in Sub-Saharan Africa. Therefore, this study makes a significant contribution to the literature on sexual behavior among young adolescents by shedding light on some key demographic and psychosocial predictors of sexual debut among this group.

\section{REFERENCES}

1. Glasier A et al., Sexual and reproductive health: a matter of life and death, Lancet, 2006, 368(9547):1595-1607.

2. United Nations Population Fund (UNFPA), Sexual and Reproductive Health for All: Reducing Poverty, Advancing Development and Protecting Human Rights, New York: UNFPA, 2010.

3. Lloyd CB et al., eds., Growing Up Global: The Changing Transitions to Adulthood in Developing Countries, Washington, DC: National Academies Press, 2005.

4. Patton GC et al., Global patterns of mortality in young people: a systematic analysis of population health data, Lancet, 2009, 374(9693):881-892.

5. Gupta N and Mahy M, Sexual initiation among adolescent girls and boys: trends and differentials in Sub-Saharan Africa, Archives of Sexual Behavior, 2003, 32(1):41-53.

6. Conde-Agudelo A, Belizan JM and Lammers C, Maternal-perinatal morbidity and mortality associated with adolescent pregnancy in Latin America: cross-sectional study, American Journal of Obstetrics \& Gynecology, 2004, 192(2):342-349.

7. Zabin LS and Kiragu K, The health consequences of adolescent sexual and fertility behavior in sub-Saharan Africa, Studies in Family Planning, 1998, 29(2):210-232.

8. Mensch BS, Singh S and Casterline JB, Trends in the timing of first marriage among men and women in the developing world, in: Lloyd CB et al., eds. Growing Up Global: The Changing Transitions to Adulthood in Developing Countries, Washington, DC: National Academies Press, 2005, pp. 118-171.

9. Singh S, Adolescent childbearing in developing countries: a global review, Studies in Family Planning, 1998, 29(2):117-136.

10. Gipson JD, Koenig MA and Hindin MJ, The effects of unintended pregnancy on infant, child, and parental health: a review of the literature, Studies in Family Planning, 2008, 39(1):18-38.

11. World Health Organization (WHO), The Sexual and Reproductive Health of Younger Adolescents: Research Issues in Developing Countries, Geneva: WHO, 2011.

12. Okonofua F, New research findings on adolescent reproductive health in Africa, African Journal of Reproductive Health, 2007, 11(3):712 .

13. Bankole A et al., Sexual behavior, knowledge and information sources of very young adolescents in four Sub-Saharan African countries, African Journal of Reproductive Health, 2007, 11(3):28-43.

14. Neema S, Musisi N and Kibombo R, Adolescent Sexual and Reproductive Health in Uganda: A Synthesis of Research Evidence,
Occasional Report, New York: The Alan Guttmacher Institute, 2004, No. 14 .

15. Munthali AC, Chimbiri A and Zulu EM, Adolescent Sexual and Reproductive Health in Malawi: A Synthesis of Research Evidence, Occasional Report, New York: The Alan Guttmacher Institute, 2004, No. 15 .

16. Guiella G, Santé Sexuelle et de la Reproduction des Jeunes au Burkina Faso: Un Etat des Lieux, Occasional Report, New York: The Alan Guttmacher Institute, 2004, No. 12.

17. Awusabo-Asare K et al., Adolescent Sexual and Reproductive Health in Ghana: Results from the 2004 National Survey of Adolescents, Occasional Report, New York: Guttmacher Institute, 2006, No. 22.

18. Zulu EM, Dodoo FN and Chika-Ezeh A, Sexual risk-taking in the slums of Nairobi, Kenya, 1993-8, Population Studies, 2002, 56(3):311323

19. African Population and Health Research Center (APHRC), Population and Health Dynamics in Nairobi's Informal Settlements: Report of the Nairobi Cross-sectional Slums Survey (NCSS) 2000, Nairobi: APHRC, 2002

20. Costa FM et al., The role of social contexts in adolescence: context protection and context risk in the United States and China, Applied Developmental Science, 2005, 9(2):67-85

21. Jessor R, Risk behavior in adolescence: a psychosocial framework for understanding and action, Journal of Adolescent Health, 1991, 12(8): 597-605.

22. Jessor R, Turbin MS and Costa FM, Protective factors in adolescent health behavior, Journal of Personality and Social Psychology, 1998, 75(3):788-800

23. Jessor R et al., Adolescent problem behavior in China and the United States: a cross-national study of psychosocial protective factors, Journal of Research on Adolescence, 2003, 13(3):329-360.

24. Jessor SL and Jessor R, Transition from virginity to nonvirginity among youth: a social-psychological study over time, Developmental Psychology, 1975, 11(4):473-484

25. Jessor R, Description versus explanation in cross-national research on adolescence, Journal of Adolescent Health, 2008, 43(6):527-528.

26. Jessor R, Costa FM and Turbin MS, Adolescent Health and Development Questionnaire: Institute of Behavioral Sciences, Boulder, CO University of Colorado, 2002, <http://www.colorado.edu/ibs/jessor/ questionnaires/questionnaire_ahdq3.pdf>, accessed July 28, 2009.

27. Jessor $\mathrm{R}$ et al., Protective factors in adolescent problem behavior: moderator effects and developmental change, Developmental Psychology, 1995, 31(6):923-933.

28. Vazsonyi AT et al., A test of Jessor's problem behavior theory in a Eurasian and a Western European developmental context, Journal of Adolescent Health, 2008, 43(6):555-564.

29. Kabiru CW et al., Transition into first sex among adolescents in slum and non-slum communities in Nairobi, Kenya, Journal of Youth Studies, 2010, 13(4):453-471.

30. Ndugwa RP et al., Adolescent problem behavior in Nairobi's informal settlements: applying problem behavior theory in Sub-Saharan Africa, Journal of Urban Health, 2011, 88(Suppl. 2):S298-S317.

31. Jessor R, Turbin MS and Costa FM, Risk and protection in successful outcomes among disadvantaged adolescents, Applied Developmental Science, 1998, 2(4):194-208

32. Spencer JM et al., Self-esteem as a predictor of initiation of coitus in young adolescents, Pediatrics, 2002, 109(4):581-584.

33. Zulu EM et al., Overview of migration, poverty and health dynamics in Nairobi City's slum settlements, Journal of Urban Health, 2011, 88(Suppl. 2):S185-S199.

34. Emina J et al., Monitoring of health and demographic outcomes in poor urban settlements: evidence from the Nairobi Urban Health and Demographic Surveillance System, Journal of Urban Health, 2011, 88(Suppl. 2):S200-S218.

35. Fotso JC, Ezeh A and Oronje R, Provision and use of maternal health services among urban poor women in Kenya: what do we know 
and what can we do? Journal of Urban Health, 2008, 85(3):428-442.

36. Fotso JC et al., What does access to maternal care mean among the urban poor? Factors associated with use of appropriate maternal health services in the slum settlements of Nairobi, Kenya, Maternal and Child Health Journal, 2009, 13(1):130-137.

37. APHRC, Policy and Program Issues Emerging from APHRC's Education Research in Urban Informal Settlements of Nairobi, Kenya, Occasional Report, Nairobi, Kenya: APHRC, 2008, No. 2.

38. Ezeh AC, Kodzi I and Emina J, Reaching the urban poor with family planning services, Studies in Family Planning, 2010, 41(2):109-116.

39. Beguy D et al., Timing and sequencing of events marking the transition to adulthood in two informal settlements in Nairobi, Kenya, Journal of Urban Health, 2011, 88(Suppl. 2):S318-\$340.

40. Kabiru CW et al., HIV/AIDS among youth in urban informal (slum) settlements in Kenya: what are the correlates of and motivations for HIV testing? BMC Public Health, 2011, 11(1):685.

41. Kenya National Bureau of Statistics (KNBS) and ICF Macro, Kenya Demographic and Health Survey 2008-09, Calverton, MD, USA: KNBS and ICF Macro, 2010.

42. Koenig MA et al., Coerced first intercourse and reproductive health among adolescent women in Rakai, Uganda, International Family Planning Perspectives, 2004, 30(4):156-163.

43. Crocker L and Algina J, Introduction to Classical and Modern Test Theory, Belmont, CA: Wadsworth, 1986.

44. Hillis SD et al., Adverse childhood experiences and sexual risk behaviors in women: a retrospective cohort study, Family Planning Perspectives, 2001, 33(5):206-211.

45. Jewkes R and Abrahams N, The epidemiology of rape and sexual coercion in South Africa: an overview, Social Science \& Medicine, 2002, 55(7):1231-1244.

46. Babalola S, Tambashe BO and Vondrasek C, Parental factors and sexual risk-taking among young people in Côte d'Ivoire, African Journal of Reproductive Health, 2005, 9(1):49-65.

47. Biddlecom A, Awusabo-Asare K and Bankole A, Role of parents in adolescent sexual activity and contraceptive use in four African countries, International Perspectives on Sexual and Reproductive Health, 2009, 35(2):72-81.

48. Huebner AJ and Howell LW, Examining the relationship between adolescent sexual risk-taking and perceptions of monitoring, communication, and parenting styles, Journal of Adolescent Health, 2003, 33(2):71-78.

49. Rostosky SS et al., The impact of religiosity on adolescent sexual behavior: a review of the evidence, Journal of Adolescent Research, 2004 19(6):677-697.

50. Ramirez-Valles J, Zimmerman MA and Newcomb MD, Sexual risk behavior among youth: modeling the influence of prosocial activities and socioeconomic factors, Journal of Health and Social Behavior, 1998, 39(3):237-253.

51. Ajayi AA et al., Adolescent sexuality and fertility in Kenya: a survey of knowledge, perceptions, and practices, Studies in Family Planning, 1991, 22(4):205-216.

52. Kaufman CE et al., Communities, opportunities, and adolescents' sexual behavior in KwaZulu-Natal, South Africa, Studies in Family Planning, 2004, 35(4):261-274.

53. Hallfors D et al., Supporting adolescent orphan girls to stay in school as HIV risk prevention: evidence from a randomized controlled trial in Zimbabwe, American Journal of Public Health, 2011, 101(6):1082-1088

\section{RESUMEN}

Contexto: Es necesario entender mejor los diferentes factores sociales, psicosociales y conductuales asociados con la actividad sexual de los adolescentes jóvenes en varios entornos del África subsahariana.
Métodos: Los datos fueron obtenidos a partir de las Etapas 1 (2007-2008) y 2 (2009) del estudio de Transición a la edad adulta, que recolectó información sobre factores clave en la transición a la edad adulta y sobre las características sociales, demográficas y psicosociales de hombres y mujeres jóvenes que vivían en dos asentamientos informales en Nairobi, Kenia. A través de un análisis de regresión logística, se examinaron las variables asociadas con la experiencia del debut sexual, en la Etapa 2, de los jóvenes que tenían 12-16 años y eran sexualmente inexpertos en la Etapa 1.

Resultados: De los 1.754 jóvenes de la muestra, 92 experimentaron su debut sexual entre las dos etapas de la encuesta. Tanto para los hombres como para las mujeres, el debut sexual demostró estar asociado con el hecho de haber abandonado la escuela definitivamente (cociente de probabilidad de 6,9 y 21,8 respectivamente), de no haber asistido nunca a la escuela $(8,6$ y 39,4) y de haber experimentado una seria disfunción familiar (2,8 y 5,7 respectivamente). La falta de supervisión por parte de los padres demostró ser un factor de predicción del debut sexual solamente entre los hombres (10,1), mientras que la falta de aspiraciones lo fue solamente entre las mujeres $(10,4)$. Sorprendentemente, tanto las mujeres como los hombres jóvenes que no tenían alta autoestima mostraron una menor probabilidad de tener su primera relación sexual entre las etapas de la encuesta $(0,4$ y 0,3) que quienes sí la tenían.

Conclusiones: Los hallazgos del estudio subrayan la importancia de la disfunción familiar, la supervisión de los padres, la participación cívica y la autoestima como determinantes de la conducta sexual en este grupo de edad. Es necesario realizar estudios adicionales para elucidar cómo se puede abordar estos factores en los programas de prevención dirigidos a jóvenes adolescentes.

\section{RÉSUMÉ}

Contexte: Il existe un besoin de mieux comprendre les divers facteurs sociaux, psychosociaux et comportementaux associés à l'activité sexuelle des jeunes adolescents dans divers contextes d'Afrique subsaharienne.

Méthodes: Les données proviennent des vagues 1 (20072008) et 2 (2009) de l'étude Transition to Adulthood, basée sur l'information collectée sur les marqueurs clés de la transition vers l'âge adulte et les caractéristiques sociales, démographiques et psychosociales des jeunes hommes et femmes vivant dans deux quartiers marginaux de Nairobi (Kenya). L'étude procède par analyses de régression logistique pour examiner les variables associées à l'expérience des premiers rapports sexuels à la vague 2 parmi les jeunes âgés de 12 à 16 ans sans expérience sexuelle à la vague 1 .

Résultats: Des 1.754 jeunes compris dans l'échantillon, 92 avaient vécu leurs premiers rapports sexuels entre les deux vagues de l'enquête. Chez les garçons comme chez les filles, le moment des premiers rapports sexuels est associé positivement à la déscolarisation permanente (OR, 6,9 et 21,8, respectivement), à l'absence totale de scolarisation $(8,6$ et 39,4) et à l'expérience d'un grave dysfonctionnement familial (2,8 et 5,7). L'absence de surveillance parentale ne s'avère un prédicteur de premiers rapports que du côté masculin $(10,1)$, 
alors que les faibles aspirations le sont côté féminin seulement $(10,4)$. Etonnamment, les jeunes femmes, comme leurs homologues masculins, dont l'estime personnelle était plutôt faible se révèlent moins susceptibles que les autres d'avoir eu leurs premiers rapports sexuels entre les vagues 1 et $2(0,4$ et 0,3).

Conclusions: Les résultats de l'étude soulignent l'importance du dysfonctionnement familial, de la surveillance parentale, de la participation civique et de l'estime de soi dans la détermination du comportement sexuel dans le groupe d'âge considéré. Des études plus approfondies permettraient d'éclaircir l'approche à adopter à l'égard de ces facteurs dans les programmes de prévention visant les jeunes adolescents.

\section{Acknowledgment}

The Transitions to Adulthood study was part of a larger project, the Urbanization and Poverty Health Dynamics project, funded by the Wellcome Trust (grant GR 07830M). This project was nested in the Nairobi Urban Health and Demographic Surveillance System, which is part of the INDEPTH Network. Analysis and writing time for colleagues at the African Population and Health Research Center was supported by funding from the William and Flora Hewlett Foundation (grant 2009-4051); the Rockefeller Foundation (grant 2009-SCG 302); the Monitoring, Learning and Evaluation project, funded by the Bill \& Melinda Gates Foundation (grant 52037); and the STEP UP (Strengthening Evidence for Programming on Unintended Pregnancy) Research Programme Consortium, funded by UKaid from the Department for International Development (grant SR1109D-6).

Author contact: milly.marston@lshtm.ac.uk

\section{Acknowledgment to Reviewers}

The editors wish to express their appreciation to the following reviewers for their assistance in evaluating material for International Perspectives on Sexual and Reproductive Health in 2012:

$\begin{array}{ll}\text { Elizabeth Aahman } & \text { Jeffrey Bingenheimer } \\ \text { Carla AbouZahr } & \text { John Bongaarts } \\ \text { Ramesh Adhikari } & \text { Sarah Bradley } \\ \text { Saifuddin Ahmed } & \text { Bruce Caldwell } \\ \text { Halida Akhter } & \text { Sanjukta Chaudhuri } \\ \text { Lukasz Aleksandrowicz } & \text { Andreea Creanga } \\ \text { Keera Allendorf } & \text { Abhijit Das } \\ \text { Graciana Alves Duarte } & \text { Jeffrey Edmeades } \\ \text { Stella Babalola } & \text { Amir Erfani } \\ \text { Patricia Bailey } & \text { Karen Foreit } \\ \text { Akinrinola Bankole } & \text { Alfredo Fort } \\ \text { Stan Becker } & \text { Bina Gubhaju } \\ \text { Deborah Billings } & \text { Christophe Guilmoto } \\ \text { Sunnee Billingsley } & \text { Davidson Gwatkin }\end{array}$

Vahe Gyulkhasyan
Karen Hardee
SD Iyengar
Shireen Jejeebhoy
Heidi Johnston
Bregje de Kok
Joan Kraft
Kathleen Kurz
Lisa Langhaug
Catherine MacPhail
Matthews Mathai
Therese McGinn
Ann Moore
Axel Mundigo

\author{
Francis Obare \\ Sabu Padmadas \\ Tia Palermo \\ Edith Pantelides \\ Rukmini Potdar \\ Mahesh Puri \\ Anita Raj \\ Roger Rochat \\ Ghazaleh Samandari \\ Nasra Shah \\ Bussarawan \\ Teerawichitchainan \\ Michael Vlassoff
}

